\title{
DIE DOEL EN PLEK VAN LIGGAAMLIKE OPVOEDING IN DIE OPVOEDINGSPROGRAM.
}

\section{INOUGURELE REDE}

gehou by die aanvaarding van 'n professoraat in die Fakulteit van Opvoedkunde aan die Potchefstroomse Universiteitskollege vir Christelike Hoër Onderwys (Universiteit van Suid-Afrika) op 24 Februarie 1951

deur dr. D. P. J. SMITH.

Hooggeleerde Rektor,

Hooggeagte Here Lede van die Raad van die P.U.K. vir C.H.O., Hooggeleerde Here Professore, Dames en Here Lektore, Dames en Here van die Administrasie,

Dames en Here Studente,

Dames en Here,

Die onderwerp waarvoor ek vanaand $u$ belangstelling vra by geleentheid van die aanvaarding van 'n professoraat in Opvoedkunde is

\section{DIE DOEL EN PLEK VAN LIGGAAMLIKE OPVOEDING IN DIE OPVOEDINGSPROGRAM.}

Die beskaafde mens is van ' $n$ gedurige fisieke stryd om selfbehoud en sekerheid van bestaan geleidelik onthef. Sy stryd teen die natuur is in baie opsigte grotendeels oorwin: die klimaat, deur kleding en woning; voedselversekering, deur landbou en veeteelt; beweging, deur vervoermiddels om hom te verplaas; bewerking en beskerming, deur gereedskap en wapens; hy beskik oor vaste verblyfplekke in plaas van te swerf en te soek; sodat 'n groot stuk fisieke inspanning en kragsverbruik weggeval en dus vrygekom het vir waarneming, oordenking en organisering van sy ervaringe. Hierdeur het in 'n bepaalde opsig 'n geordende maatskappy ontstaan. Dit het al meer en meer in ingewikkeldheid toegeneem, al meer geestelike en minder liggaamlike arbeid vereis; al meer bemeesterde kultuurgoedere en lewensgeriewe is vir die volgende geslagte nagelaat. Hierdie weg het vir die mens ,natuurlik" geword en niemand sal met die proses fout wil vind of die vermindering van die fisieke stryd om te bestaan betreur nie. Die beginsel is korrek en moet voortwerk. Die klem het verskuif van fisieke na geestelike strydmiddels en van fisieke selfhandhawing na geestelike weerbaarheid, en aanvaarding hiervan het geestelike skoling vereis, terwyl fisieke bekwaamhede en 
waardes al meer op die agtergrond gedring is. Oor die kanse om suksesvol op hierdie weg voort te gaan, sê Korpershoek dat dit kan wees dat hierdie prinsipe en proses ,die ons geestelijk en organisatorisch zoo ver voerden als wij thans zijn, ons ten slotte ten verderve zullen leiden, tenzij wij de nadelige effekten van het principe weten te compenseeren." (15).

Weliswaar hoef die moderne mens nie oor dieselfde krag en arbeidsvermoë, ongevoeligheid teen klimaat, onreëlmatigheid in voeding en lewe soos die primitiewe jagter te beskik nie. In die primitiewe staat het die geestelike ontwikkeling 'n agterstand gehad teenoor fisieke prestasie net soos die omgekeerde vandag waar is. Die mens het in sy opvoeding van een pool na die ander gegaan en tog nie veilig tussen Scylla en Charybdis deurgestuur nie.

Die aangewese plek wat liggaamlike opvoeding in die opvoedingsprogram van die geordende maatskappy behoort in te neem, moet bepaal word deur die bydrae wat dit tot die totale opvoeding van die mens lewer. Sodanige bydrae is die produk van 'n vooropgestelde doel. Die behandeling van my onderwerp vereis dan in die eerste plek ' $n$ beantwoording van die vraag wat die doel van liggaamlike opvoeding is, nie soos dit algemeen aanvaar word nie, maar wat volgens my mening nagestreef behoort te word. Trouens, so'n algemeen aanvaarde doel bestaan in die liggaamlike opvoeding net so min as in die verstandelike opvoeding.

Die geskiedenis van die liggaamlike opvoeding toon an hoe die brandpunt van belangstelling deur die eeue verwissel en veral in die afgelope kwarteeu verskuif het. 'n Besonder belangrike faktor wat hierdie verskuiwing veroorsaak en die doel en karakter van die liggaamlike opvoeding van elke tydperk bepaal het, was die opvatting oor die verhouding van gees en liggaam.

Die Grieke van Athene het geglo dat daar 'n verband tussen gees en liggaam bestaan en dat die ontwikkeling van die een wel die ander beinvloed. Geen ander beskaafde volk het daarna in hulle opvoedingsprogram 'n groter plek aan die liggaamlike opvoeding toegeken as die Atheners nie. Plato sê in "Die Staat” egter dat die musiek en die gimnastiek nie die siel en die liggaam onderskeidelik ontwikkel nie, maar dat die onderwysers van albei hoofsaaklik die siel verbeter. (1).

Gedùrende die Middeleeue het die kerk 'n soortgelyke maar anders gestelde beskouing daarop nagehou. Die liggaam en die siel is as twee afsonderlike entiteite beskou en eersgenoemde se pyniging en onderdrukking sou dan tot heiliging van die siel dien. Vir die vrymaking van die siel van die kwaad is die askese beoefen, die vlees is as het ware gekruisig, die mens was ,in oorlog" teen homself. 
Die Renaissance het hierdie opvatting gewysig, en 'n nuwe tydperk ook op politieke, sosiale, ekonomiese en godsdienstige gebied ingelui. In Italië is vorsteskole in die lewe geroep waarvan die te Mantua onder Vittorino de Feltre vir ons die grootste betekenis het. Sy teorie en praktyk waarin liggaamsoefeninge 'n vername rol gespeel het, het in direkte teëstelling tot die van die Middeleeue gestaan.

Hoewel die humanistiese opvattinge betreffende die dissiplinerende waarde van tale en letterkunde die opvoeding tot dic middel van die neëntiende eeu gedomineer het, het die realiste, reeds in die $17 \mathrm{e}$ ceu, en veral Michel de Montaigne, die liggaamlike opvoeding beklentoon omrede sy dissiplinerende waarde. (1) „Dit is nie 'n siel, dit is nie 'n liggaam wat ons opvoed nie maar' $n$ mens, en ons mag die nie in twee dele verdeel nie," sê Montaigne. Die rewolusionêre natuurpedagoog, Rousseau, het beweer dat die opvoeding van die kind so'n totaliteit vorm, dat hy nie in staat is om te bepaal wanneer ' $n$ aktiwiteit van 'n intellektuele of sedelike tot 'n liggaamlike oorgaan nie. Basedow het in sy Philantropinium te Dessau daagliks onderrig in liggaamlike opvoeding gegee en 'n heel moderne en wye program aangebied. GutsMuths het hierop verbeter en 'n verreikende invloed uitgeoefen veral op die liggaamlike opvoeding in Duitsland, Denemarke, Swede, Switserland en Engeland. (5)

Geeneen van sy voorgangers het die ondeelbare cenheid van die mens egter so benadruk en op so'n aanskoulike wyse oor die vorming van hoof, hart en hand gepraat as Pestalozzi (9) nie. In sy skerp kritiek op die skole van sy tyd oor die eensydige intellektualisme en die verontagsaming van dic eenheid van die opvoeding lewer hy die mooi uitspraak: „Die Natur gibt das Kind als ein untrennbares Ganzes, als eine wesentliche organische Einheit mit vielseitigen Anlagen des Herzens, des Geistes, des Körpers." (9) Hy het in die ontwikkeling van die een 'n voorwaarcle vir en 'n verband met die ontwikkeling van die ander gesien.

Die gedagtes van Pestalozzi het ondersteuning gevind in nuwe pedagogiese rigtinge wat die intellektualistiese eensydigheid van die luisterskool vervang het met 'n opvoeding tot aktiwiteit en selfstandige werksaamheid. Fröbel het sy opvoedingsprogram op die bestudering van die kindernatuur, -belangstelling en -behoeftes gebou, omdat hy geglo het dat die kind deur skeppende aktiwiteite moet leer. Deur spele sou goeie gewoontes op die gevoel, die denke en die handeling ingeënt word. Ander voorbeelde van hierdie nuwe rigting is die Montessori- en Daltonskole, die „Lebensgemeinschaftschulen" van Petersen, die Projekplanskole van Dewey en Kilpatrick en die skool van Decroly in België. (9) 
Diè opvatting moet dan ons uitgangspunt wees dat die liggaamlike opvoeding 'n wesenlike deel van die hele opvoeding is omdat die liggaam 'n wesenlike deel van die mens is. Gods Woord leer ons eerbied en hoogagting vir die liggaam want dit is ook Sy Skepping. Maar by die bepaling van die doel van liggaamlike opvoeding moet egter ook gewaak word teen 'n oorskatting van die liggaam, want die mens is nie net liggaam nie. Die liggaamlike opvoeding moet weliswaar die ontwikkeling van die liggaam en die versterking van sy organe beoog, maar die nadruk moet val op die opvoeding van die hele mens cleur middel van die liggaam. Om hierdie rede moet die doel van liggaamlike opvoeding by die doel van die hele opvoeding ingepas word.

Hoe fundamenteel 'n voorafbepaalde doel in die opvoeding is, word in die geskiedenis van die opvoeding duidelik weerspieël. "We may shape our educational system to produce almost any ends we desire," meen McCloy. (20) Die Spartane het liggaamlike gehardheid en die Atheners skoonheid en harmonie as doelwit gestel en dit in 'n hoë mate bereik. Duitsland, voor 1914, het intellektuele meesterskap nagestreef en dit grotendeels verwerf. Nasionaal-sosialistiese Duitsland het die icleë van volksgemecnskap, leierskap, rassebewussyn en weerbaarheid as doel van sy opvoeding gestel en dit met besondere sukses deurgevoer. Engeland het 'n karakteropvoeding, 'n hoë moreel vir sy burgers beoog en Kandel getuig dat die ideaal deur sport verwesenlik is. Die Verenigde State van Amerika het in sy strewe na beroepsvoorbereiding besondere sukses behaal. Rusland se vernaamste slagkreet is opvoeding tot gereedheid vir arbeid en verdediging, en die Westerse Wêreld ervaar recds hoe skrikwekkend hy hierin slaag.

'n Bestudering van die verskillende „stelsels” en rigtinge in die liggaamlike opvoeding openbaar 'n verskeidenheid van doelstellinge. Die Sweedse gimnastiek van Ling (3) en die metode van Mensendieck (21) wou vormend en korrektief werk: 'n verbetering van die liggaamsbou en liggaamshouding verseker. Jahn (5) het 'n politieke doel nagestreef en wou deur sy gimnastiek die vaderlandsliefde opwek en die weerbaarheid van 'n verdeelde en oorheerste Duitse volk verhoog. Die ritmiese gimnastiek en die moderne dansrigting beoog die estetiese ontwikkeling, die ontwikkeling van mooi beweginge. Die biologiese rigting wat die ontwikkeling van die organe en die vernaamse faktore van liggaamlike bekwaamheid, krag, snelheid, behendigheid en uithouvermoë insluit, het verreweg die oudste en dic meeste verteenwoordigers en dit word tereg ook vandag in elke program van liggaamlike opvoeding gevind.

In sy behandeling van die filosofiese grondslae van die liggaamlike opvoeding maak McCloy (20) ' $n$ indeling in twee tydperke: voor 
Thorndike, toe die doel van liggaamlike opvoeding hoofsaaklik die fisieke benadruk het, en na Thorndike toe vir die liggaamlike opvoeding die liggaam hoofsaaklik as middel moes dien waardeur die mens opgevoed kon word. Thorndike se opvoedkundige siekunde is seker die die liggaam hoofsaaklik as middel moes dien waardeur die mens die sterkste enkele invloed op die moderne liggaamlike opvoeding van ons tyd. Die sosiaal-opvoedkundige doel, karaktervorming en sosiale aanpassing, word deur die meeste leidende liggaamsopvoeders, veral in Amerika van besondere belang geag.

By die verskillende rigtinge in die intellektuele opvoeding bestaan 'n dergelike verskeidenheid wat die noodsaaklikheid van 'n samevatting en rangskikking van die talryke oogmerke laat ontstaan het. Dit is gedoen deur 'n kommissie van die „National Education Association” van Amerika wat al die verskillende oogmerke van die opvoeding onder sewe hoofde, die „Seven Cardinal Principles of Education” ingeskakel het. (16) Hulle is: gesondheid, beheer oor die fundamentele prosesse, 'n waardige gesins-, burgerlike, en beroepslewe, die nuttige gebruik van vrye tyd, en karaktervorming. Geen enkele terrein alleen kan hierdie eienskappe volledig voorsien nie en die verskillende dele van die opvoeding sal gesamentlik moet bydra om onder andere tot resultaat te hê: 'n volwasse, goedfunksionerende liggaam, innig verbonde met 'n intellektuele en maatskaplike rypheid, 'n mens geestelik en liggaamlik bekwaam gemaak om goeie diens te lewer.

Ons wil die sewe kardinale oogmerke van die opvoeding as basis van bespreking stel en kortliks nagaan watter bydrae die liggaamlike opvoeding tot elkeen kan lewer.

Die bevordering van GESONDHEID moet nie gesoek word in die uitskakeling van vergiftigende faktore of besmetting deur bakterieë nie maar wel in ' $n$ volledige groei en ontwikkeling van die liggaam, m.a.w. in 'n uitskakeling van liggaamlike swakheid wat 'n verlies aan lewenslus en 'n lae geestelike en sosiale produktiwiteit ten gevolg het. Kroniese liggaamlike steuringe, sê Spencer, werp skaduwees oor die skitterendste vooruitsigte, terwyl die lewenskrag van 'n goeie gesondheid die ongeluk nog kan verguld. (15)

In die lig van gegewens tot ons beskikking* is die stelling geregverdig dat die kultuurproses van die moderne tyd veral soos in die skool beliggaam, die mens fisies verswak en op sy biologiese ontwikkeling

\footnotetext{
* Die ondersoekinge vir hierdie bespreking gekies, het veral betrekking op kinders in die eerste skooljare en hoe hulle vergelyk met kinders van dieselfde leeftyd wat nie die skool besoek het nie. Die tendens tot 'n groeivertraging by soolgaande kinders blyk uit verskillende ondersoekinge.
} 
belemmerd inwerk en dat liggaamlike opvoeding die gewenste groeiprikkels kan verskaf on die belemmerende faktore uit te skakel.

Schmid-Monnard (15) het 'n ondersoek met twee groepe kinders in Halle uitgevoer. Die liggaamlik welgestelde groep wat tussen die sesde en sewende lewensjaar tot die skool toegelaat is, het 'n daling in lengteen gewigstoename getoon, terwyl die groep wat juis weens liggaamlike agterlikheid vrygestel was van skoolbesoek, reëlmatig daarin toegeneem het. Die vordering van laasgenoemde groep kan egter ook aan gunstiger lewensomstandighede toegeskryf word. Bürgerstein (15) het 'n vertraging van die gewigstoename by laerskoolkinders vasgestel veral by die wat van huis uit swak was en bevestig daarmee die bevindinge van Schmid-Monnard. Ook Quirsfeld (15) het in 'n ondersoek van 1014 kinders in Noord-Boheme ' $n$ vermindering in spierontwikkeling by 29.59 persent seuns en 49.05 persent dogters gevind. Die liggaamlik agterlike kinders in die „Schulkindergarten" te Bonn, daarenteen, het hulle normale maats verbygegroei omdat hulle, volgens die ondersoekers, van die nodige groeiprikkels deur voldoende spieraktiwiteit en 'n higiëniese leefwyse voorsien was.

'n Opname deur Hertel (15) van 3650 kinders uit die arbeidersklasse in Denemarke het aan die lig gebring dat die siektepersentasie 18.4 is by die aanvang van die skoolloopbaan, daarna styg dit tot 34 persent teen die einde van die eerste skooljaar, ęn bly op daardie hoogte tot kort voor puberteit, wanneer dit plotseling styg tot 40 persent. Die gevolgtrekking hierdit is dat die skool diep ingryp in die kinderontwikkeling en dat die teëstelling tussen die natuurlike en die kulturele ontwikkeling te groot is. Röder en Wienecke (15) het vasgestel dat 'n staptoer die groeitoename bevorder het, ' $n$ toename wat afwesig was by kinders van dieselfde leeftyd wat gedurende dieselfde tyd in die skool agter gebly het.* Dat liggaamsbeweging en spieroefening uiters belangrike prikkels verskaf vir die afskeiding van spysverteringsappe, is deur Bickel in 'n grondige ondersoek aangetoon.

Op die middelbare skool en aan die universiteit is die toestand niks beter nie. Rowe (27) het vasgestel dat seuns wat op die middelbare skool liggaamlike opvoeding geniet het van 30 tot 90 persent meer toegeneem het in gewig, longkapasiteit en greepkrag as seuns wat nie die oefeninge bygewoon het nie. Hy kon ook vasstel dat oormatige oefening skadelik is, want gedurende die wedstrydseisoen het die voetbalspelers 40 tot 60 persent minder ontwikkel as die wat liggaamlike opvoeding gedoen het. Veeleisende wedstryde is dus vir die middelbare

* Aan die staptoer het 500 kinders deelgeneem en hulle is met 150 kinders vergelyk wat nie aan die staptoer deelgeneem het nie. 
skoolseun af te keur totdat die vinnige groeiperiode op ongeveer sestien jaar voltooi is. Dit hang saam met die grootte van die hart en sy ontwikkeling in verhouding tot die hele liggaam. Gedurende die vinnige groeiperiode, twaalf tot sestien jaar, moet aktiwiteite dikwels maar altyd matig toegepas word. 'n Verskerping van die program kan daarna plaasvind vir die opbou van krag en uithouvermoë.

In 'n ondersoek na die geskiktheid vir militêre diens in Switserland het Messerli (15) Lausanne, gevind dat persone wat liggaamlike opvoeding geniet het die grootste persentasie uitgemaak het. Hy besluit dat daar 'n sieklike, oormatige lentegroei is, en 'n wanverhouding tussen lengte en borsomvang as gevolg van die sittende lewe van die studente.

Godin en Matthias (15) het in 'n omvattende ondersoek die invloed van sistematiese gimnastiek op die groei gedurende die puberteitsperiode nagegaan. Die 700 gimnaste, twee groepe wat onderskeidelik, $2+$ jaar en 'n $\underline{z}$ jaar geoefen het, is toe vergelyk met 135 studente van 'n opleidingskollege vir onderwysers wat dieselfde leeftyd gehad het. Die aspirantonderwysers het in alle opsigte die swakste liggaamlike ontwikkeling gehad; daarop volg die gimnaste wat 'n $\frac{1}{2}$ jaar geoefen het met ' $n$ veel beter ontwikkeling; terwyl die met 21 jaar oefening die beste fisieke ontwikkeling getoon het.

Die noodsaaklikheid van liggaamlike opvoeding is egter nie beperk tot die skool nie. Die uitwerking wat die beroepslewe op die liggaamlike ontwikkeling uitgeoefen het, is nagegaan deur Kaup. (15). Hy het gevind dat beroepe wat die aktiwiteit beperk, 'n ongunstige uitwerking gehad het. Persone wat sodanige beroepe volg en liggaamsoefeninge doen, skakel die ongunstige invloede uit.

McCloy (20) glo dat „premature old age is a function of three things: a lack of strength, a growing inflexibility, and an attitude of mind." Van die eerste sê hy dat, indien die liggaamskrag toegelaat word om af te neem namate die jare toeneem, 'n gebrek aan uithouvermoë sal volg; van die tweede, dat veerkragtigheid afneem, styfheid volg en die antagonistiese spiergroepe verkort en mekaar teëwerk; die derde, is die geesteshouding om jou oud te hou, of dink te wees, wat die gevolg van minderwaardigheid is wat kompensasie soek in 'n poging tot 'n waardige voorkoms. Die feit is dat die kragte nie so gou afneem as snelheid nie en hoewel liggaamlike opvoeding die lewe nie kan verleng nie, sal dit die verlenging van fisiologiese jeugdigheid tot ver in kronologiese bejaardheid meebring.

Karpovich (14) en Hawkins (11), onderskeidelik, het die invloed van oefening op die samestelling van die bloed nagegaan en gevind dat nie slegs bloedvorming plaasvind nie maar dat witbloedliggaampies ver- 
meerder deur oefening, wat aan 'n herverdeling van die bloed en 'n vrystelling van witbloedliggaampies uit hulle reserwe-voorrade toe te skrywe is.

Statistieke toon aan dat senuweesiektes in die moderne tyd die meeste beddens in die hospitale eis. Met die versteuring van die emosionele ewewig het die byniere, volgens Crile, (20) heclwat te doen. Die adrenalien wat deur die buislose kliere afgeskei word, stel die mens tot energieke optrede in noodtoestande in staat. Deur fisieke inspanning word die adrenalien geoksideer en dit laat die indiwidu ontspanne en rustig. By die moderne mens skei die byniere nog adrenalien af maar dit lei gewoonlik nie tot energieverbruik nie. Dit lei egter tot 'n senuweeen spierspanning waarop emosionele onstabiliteit volg. Hieruit volg dat ook liggaamlike aktiwiteit van belang is om emosionele versteuringe te te werk.

Die tweede oogmerk wat aan 'n wetenskaplike bespreking onderwerp moet word, is die beheer oor die FUNDAMENTELE PROSESSE. 'n Vroeëre opvatting was dat die fundamentele prosesse in die opvoeding slegs uit lees, skryf en reken bestaan. In die moderne lewe sou hierdie middels beslis nie voldoen aan die kulturele eise nie. Die skool, ja selfs die laerskool, moet die fundamentele kennis lewer, maar nie net kennis nie maar ook 'n lewenshouding, 'n persoonlikheid, 'n maatskaplik volwaardige mens. Die indiwidu moet nie slegs geestelik gevorm word nie maar ook liggaamlik, want die totale vorming gaan sy optrede, gedraginge, handelinge en reaksies bepaal. Die liggaamlike vorming van die mens is gevolglik ook van fundamentele betekenis. Die indiwidu moet beskik oor die noodsaaklike intellektuele en liggaamlike middele vir sy bestaansbeveiliging, veral omdat so baie kinders die beroepslewe na afloop van hulle laerskoolloopbaan betree. Dit sal noodlottig wees indien 'n persoon lomp en onhandig vertoon want dit is kentekens van 'n laer geestelike nivo. Deur geestelike en liggaamlike vorming word die bewegings seker, beheersd, beslis en rustig-die uiterlike tekens van 'n ewewigtige persoonlikheid.

Oor die bydrae van liggaamlike opvoeding tot sodanige fisieke optrede sal niemand seker twyfel nie. Nie slegs op skool nie maar ook in die beroepslewe word te veel persone aangetrè wat fisies benede standaard is en ook agterlik is wat senuwee-spierkoördinasie betref. Sodanige persone sal ontspanningsaktiwiteite in die latere lewe nie kan geniet of waardeer nie en selfs vermy, omdat hulle fisies minderwaardig voel en spier- en orgaankrag mis.

Die liggaamlike opvoeding kan op die GESINSLEWE 'n merkbare invloed uitoefen. Die liggaamsopvoeder het 'n gunstige geleentheid om 
die kind te leer ken en met die ouer te beraadslaag oor sy probleme. Die aktiwiteite wat oorgedra kan word tot die huisgesin en tuis beoefen word, sal die band tussen ouer en kind hegter maak. Dit sal aanleiding gee tot ontspanningsgeriewe in die huis en in die agterplaas, wat die kind se huis 'n aangename plek sal maak en daarmee die behoefte aan buitenshuise ontspanning, meestal van gekommersialiseerde aard, teëwerk.

'n WAARDIGE BEROEPSLEWE vereis van die indiwidu dat hy toegerus sal wees om vir homself en sy afhanklikes te sorg, om die gemeenskap deur sy beroep nuttig te dien, en sy moontlikhede ten volle tot ontplooiing te laat kom. Dit is skynbaar vergesog om te verwag dat liggaamlike opvoeding ook tot hierdie doel sal kan bydra, veral tot die moderne beroepslewe waar elektrisiteit en masjinerie die hande-arbeid vervang het en die meeste beroepe geen besondere spierinspanning vereis nie. Die vraag ontstaan verder of dit nou juis nodig is om die gebruik van liggaam as bewegings- en arbeidsapparaat tot groter hoogtes te voer as wat deur die beroep vereis word. Daar bestaan, veral vandag, geen sekerheid dat die rustige verhoudinge van ons bestaan nic plotseling kan verander en buitengewone eise aan die liggaam gestel word nie. Dit is dus 'n wyse beleid om die opvoedingsprogram met die oog op 'n breë veld van moontlikhede in te rig en die mens volkome toe te rus vir aanpassing onder verskillende omstandighede.

Maar afgesien van die praktiese waarde is ' $n$ volledige opvoeding nodig waarin die liggaamlike nie verwaarloos sal wees nie.

Korpershoek (15) meen dat dit die hele psigiese gesteldheid, die persoonlikheid, ja selfs die lewensvisie sal beïnvloed, indien 'n mens weet dat jy 'n liggaam besit wat alle moeilikhede kan oorwin, 'n liggaam wat volkome beheer word deur die wil en waarop mens ten volle kan vertrou. Hiervoor is 'n presiese kennis van ons liggaamlike vermoëns nodig, en dit kan die beste deur liggaanlike opvoeding verkry word.

As gevolg van die innige verband tussen gees en liggaam sal vermoeienis van die een ook vermoeienis van die ander meebring. Al hang liggaamlike prestasie ook af van geestelike faktore soos wilskrag, belangstelling, ens. beskik die liggaamlik geoefende persoon oor 'n groter reserwekrag of uithouvermoë as die ongeoefende. Hy sal dus nie slegs tot hoër produktiwiteit in sy beroep in staat wees en langer teen 'n hoë tempo kan werk nie maar sal teen die einde van die dagtaak nog vol energie wees, wat sy vatbaarheid vir siekte sal verminder, want vermoeidheid verlaag die weerstand teen siekte. In 'n ondersoek na die implikasies van siekte het Taylor (28) aangetoon dat'n goeie produksie 
en sukses in industrieë sowel as in opvoedingsinrigtinge van goeie gesondheid en liggaamlike geskiktheid afhang.

Die bydrae van liggaamlike opvoeding tot ' $n$ GOEIE BEROEPSLEWE word bewys deur 'n ondersoek van Thisted (29) na die verhouding tussen deelname aan sport op universiteit en sukses in die beroep. Hy vind dat die grootste persentasie sportmanne aansienlik hoër salarisse verdien. "This investigation shows that students participating to a considerable or great extent in intercollegiate athletics show no evidence of having been handicapped by this participation, either while in college or in later vocational life." Die klag dat deelname aan sport die intellektuele en beroepsvoorbereiding teëwerk, word deur hierdie bevinding geloënstraf.

GOEIE BURGERSKAP hang ten nouste saam met die gesins- en beroepslewe. Dit is 'n vereiste dat die kind onder geskikte omstandighede en die regte leiding geplaas moet word om gehoorsaamheid, samewerking, vaderlandsliefde en weerbaarheid, enkele eienskappe van goeie burgerskap, te ontwikkel. Ook die liggaamlike opvoeding bied besonder geskikte geleenthede vir die bevordering van hierdie eienskappe, mits die onderwyser doelbewus hierop afstuur en sy metode van onderwys hiervolgens kies. Die indiwidu ervaar in spele dat elke oortreding van die spelreëls en spelmoraal hom ongunstig tref en dat selfsugtigheid deur sy spanmaats en die toeskouers afgekeur word. Die kind leer om die regte van andere te respekteer en hom blymoedig te onderwerp aan reëls en gesag en om sy samewerking te gee tot bereiking van sukses. Die lewenssituasies kom hiermee ooreen, en ons kan verwag dat die eienskappe in 'n groot mate sal oordra.

In die begin van die neëntiende eeu het Friedrich Ludwig Jahn, vader van die Duitse gimnastiek, die grondslag van die Duitse volksgimnastiek gelê. „Dabei,” sê die geskiedskrywer Cotta, (5) „leitete ihn der patriotische Gedanke, die Körper der jungen Deutschen stark zu machen zum Kampfe gegen den Feind des Vaterlandes." In hierdie doel, die opwekking van vaderlandsliefde en die verhoging van weerbaarheid deur sy gimnastiek, het hy so uitmuntend geslaag dat oefenbyeenkomstes deur' $n$ vyandige regering deur noodregulasie verbied is. Die oogmerke van Jahn is in die liggaamlike opvoeding van nasionaal-sosialistiese Duitsland weereens vooropgestel.

Volgens La Porte (17) sal VRYE TYD die vernaamste industriële en sosiale vraagstuk van die volgende generasie wees. Die aanduidings is dat sy voorspelling korrek is. Aan voorbereiding van' die kind om sy vrye tyd nuttig te bestee, moet ' $n$ belangrike plek in die opvoeding gegee word. Die moderne tydperk word gekenmerk deur ' $n$ aansienlike inkorting van 
die werksure en die gevolglike vermeerderinng van vrye tyd. Al meer en meer word gekommersialiseerde ontspanning en vermaak aangebied en die massas deel so gewilliglik en entoesiasties daarin dat hulle die volgende werksdag moeg begin. Een middel hierteen is gesonde liggaamlike ontspanning, en kennis van sodanige ontspanningsaktiwiteite word deur die liggaamlike opvoeding voorsien. Dit verskaf lewensvreugde en verhoog die arbeidsprestasie.

Die waarde van liggaamlike ontspanning as hulpmiddel om jeugmisdaad in 'n mate teë te werk, word bewys deur verslae van die polisie in Los Angeles. (22) Die stigting van 'n seunsklub het jeugmisdaad binne dric jaar met 85 persent verminder. 'n Soortgelyke opname deur Bogardus toon aan dat die aantal arrestasies van jeugmisdadigers in die onmiddellike omgewing van 'n seunsklub na sy stigting van 106 tot 19 gedaal het. Sullenger het 1,000 families, wat jeugmisdadigers opgelewer het, ondervra en gevind dat 904 daarvan meer as 'n halfmyl van speelgronde af woon. Die Nasionale Ontspanningsbeweging van Amerika het vasgestel dat goedgeleide ontspanning die misdaadsyfer met 25 tot 75 persent verminder het. Verslae van Sing Sing toon aan dat 97 persent van die prisoniers nooit aan enige seunsklub of ontspanningsorganisasie behoort het nie. (2) Dat vrye tyd die tyd is vir wangedrag, word bewys deur Burt wat vind dat die meeste misdade plaasvind tussen 4 en 5 uur namiddag en wel in grebiede waar geen speelgronde is nie.

Die geleenthede ook van liggaamlike opvoeding om by te dra tot die SEDELIKE VORMING is ryk. In die aktiwiteite van liggaamlike opvoeding bevind die kind hom in besondere sedelike situasies wat die geleentheid bied om hulle te lei. Die uiting van emosies soos o.a. vrees, woede, simpatie, en vreugde staan in besonder noue verband met sedelike gedrag en word gewoonlik nie in die klaskamer aangetref nie maar in situasies waaraan teëstand, gevaar, selfgelding, opoffering, samewerking en lojaliteit verbonde is. Die sedelike optrede is daar besonder aktueel waar emosie en aksie die naaste aan mekaar lê: daar kan sedelike selfbeheer die beste gevorm word: daar, sề Schiller, is die mens die maklikste opvoedbaar want „er ist nur da ganz Mensch, wo er spielt."

Starbuck gaan selfs so ver dat hy tot die gevolgtrekking kom dat karakter op spiere en emosies gebaseer is. „If we determine the variety and nature of muscular activity experiences as modified by emotional experiences, we hold the key to human character." (17) Jackson het in 'n eksperimentele studie oor die invloed van vrees op spierkoördinasics (13) gevind dat vrees by 'n gimnas sy prestasies soos dic̀ van 'n beginner laat lyk. Die kwaliteit van beweging is rukkerig, swak gekoördineerd en dit lei tot beserings. Die proefpersoon „breek" sy swaai, hou te lank 
vas en gee die indruk van besluiteloosheid. Dit alles is vir die Sedelike selfbeheer nie sonder belang nie.

Remmende voorstellinge lei tot 'n minderwaardige persoonlikheid. Vrees lewer hiertoe 'n besondere bydrae en een van die belangrike oorsake daarvan moet in liggaamlike agterlikheid gesoek word. Sodanige voorstellinge kan voorkom word deur spanspele. Selfs die swakste speler, wat indiwidueel minderwaardigheid sou ontwikkel het, sal in spanspele soms die oorwinning behaal en in die vreugde daarvan deel. Die onderwyser moct ook met die oog daarop die verloop van spele beplan, sodat 'n gevoel van prestasie en sukses by die swakkere sal ontstaan. „A definite success, physical or mental, is apt to do much toward removing the sense of inferiority," skryf Burnham. (2)

Van hierdie psigologies-pedagogiese vorming kom egter weinig tereg indion die onderwyser dit nie doelbewus nastreef nie. In 'n eksperiment het Clevett (4) vasgestel dat'n strewe na die ontwikkeling van eerlikheidsin* by liggaamlike aktiwiteite nie slegs eerlikheid bevorder het nie maar ook die prestasies verhoog het. Die onderwyser mag nie maar hoop dat sedelike deugde as newe-produkte van die aktiwiteite sal ontwikkel nie. Ongewenste psigiese eienskappe soos ruheid, dominering en uitbuiting van die swakkes kan anders die gevolg wees en die liggaamlik swakke nog sterker van sy swakheid bewus maak.

Die bogenoemde „kardinale oogmerke” is egter nie voldoende nie ondat, onder andere, godsdienstige vorming erken moet word. Watter deugde en watter vorming die onderwyser ook mag nastrewe, dit moet verbind en ondergeskik wees aan die GODSDIENSTIGE VORMING van die mens. Ook die liggaamlike opvoeding bied hiertoe mooi geleenthede om 'n regte waardering van die liggaam by te bring. Enige welgesteldheill van liggaam en gees, enige deug of bekwaamheid is ' $n$ gawe van God en moet die mens nederig en dankbaar stem. Die Christen mag sy liggaam nie oorskat nie maar moet dit as gocie werktuig in diens van die God stel, as 'n middel waardeur die hele mens verbeter kan word. Ewe verkeerd is 'n onderskatting van die liggaam, want dit is die Tempel van die Heilige Gees en moet tot die beste van ons vermoë ontwikkel word. Dit staan ons derhalwe nie vry om te kies of ons die mens ook deur liggaamlike opvoeding wil lei, vorm en toerus nie. Ons moet dit doen: dit is ons plig. Dit is 'n bevel van God dat ons Hom moet verheerlik in en deur liggaam en gees.

* Ek moet daarop wys dat die beoordeling van so'n abstrakte begrip as eerlikheid enigsins subjektief is. Daar is ook geen bewyse, my bekend, dat eerlikheid in sport noodwenig tot ander lewensomstandighede oorgedra word nie. 
Met hierdie beskouinge het ek $u$ in breë trekke ' $n$ beeld probeer gee van die wetenskaplike feitekennis wat aan die waarde, doel en plek van liggaamlike opvoeding ten grondslag lê. Dit was my doel on resultate van empiriese ondersoek vas te stel en prinsipiële beskouings is slegs terloops in my rede ingevleg; in latere publikasies hoop ek om dieper in te gaan op die prinsipiële grondslae van liggaamlike opvoeding. Die vraagstuk wat die doel van liggaamlike opvoeding kan en behoort te wees, is uit die vernaamste oogmerke benader, en hieruit wil ek gevolgtrekkinge maak oor

\section{DIE PLEK VAN LIGGaAMLIKE OPVOEDING IN DIE OPVOEDINGSPROGRAM.}

Uit die aangehaalde gegewens het ons gesien dat die omstandighede waaronder die laer- en middelbare skoolkind opgroei, sy liggaamlike ontwikkeling kan strem en hom fisies minderwaardig kan maak. 'n Samevatting van die bevindinge van die verskillende ondersoekers, waaronder bioloë, medici, staatkundiges en opvoedkundiges, kom neer op die eenvoudige maar treffende uitspraak van Schanz, (15) naamlik, dat die kind wat liggaamlik goed geoefen en geskool is, die nadelige gevolge van die skoollewe minder sal ondervind as die cen wat weinig of niks aan liggaamlike opvoeding gedoen het nic.

Vir die doeltreffende toepassing van liggaamlike opvoeding wat die gestelde oogmerke sal bereik, moet dan, op grond van die bydrae wat dit tot die totale opvoeding lewer, 'n ruim plek toegeken word.

Die herhaalde eise van verskillende nasionale en internasionale kongresse vir liggaamlike opvoeding dat minstens een daaglikse lesuur, d.w.s. 5 uur per week, uitgesonderd die spelmiddae, aan liggaamlike opvoeding gewy moet word, is reeds in verskillende lande toegestaan en in die meeste lande byna bercik.

Die plek wat liggaamlike opvoeding op skole in die verskillende lande inneem, kan uit die toekenning van tyd per week afgelei word. (26) In 1938 het Tseggo-Slowakye reeds 6 uur per week aan liggaamlike opvoeding gewy. Frankryk, Japan en Turkye, elk 5 uur; Argentinië, Denemarke, Duitsland, Hongarye, Pole. Roemenië en die V.S.A., elk 4. uur; Swede en België, 8 uur daagliks: Bulgarye, Engeland, Chili, Finland, Griekeland, Iran, Italië, Nederland, Sjina en Switserland, elk 3 uur; JoegoeSlawië en Letland, elk 2 uur. Hierdie ure sluit alle verpligte spelmiddae uit. Hierteenoor stel die Nasionale Adviserende Raad vir Liggaamlike Opvoeding in Suid-Afrika die beskeie eis van drie periodes van 40 minute elk, per week. (6) Inderdaad word, weens die beklemtoning van eksamenvakke, by sommige skole slegs twee periodes en by die meeste skole slegs een periode per week aan liggaamlike opvoeding gewy, en hierdie 
voorreg word die hoër klasse soms nog heeltemal ontneem. Met so'n toestand kan geen berekenbare resultate ooit behaal word nie en sou dit onbillik wees on van liggaamsopvoeders te eis dat hulle bewyse van vrugbare arbeid sal lewer. Die gevaar van hierdie onwaardige posisie is dat onderwysers van liggaamlike opvoeding belangstelling verloor, die kinders doelloos ,besig hou," roepingsgevoel en entoesiasme kwytraak en 'n ongelukkige, onvrugbare bcroepslewe lei. Die skuld kan nie op hulle rekening geplaas word nie maar wel op die onderwysowerhede en leiers op opvoedkundige gebied, wat aan hierdie deel van die opvoeding nie sy regmatige plek in ons land toeken nie. Die eis dat die werker moet produseer, word selfs in Rusland nie gestel sonder die toekenning van redelike tyd en die voorsiening van die nodige masjinerie nie. 'n Vergelyking tussen Suid-Afrika en die ander lande van die wêreld is bepald ongunstig vir ons.

Die noodsaaklikheid vir liggaamlike opvoeding op die universiteit en die bydrae wat dit kan lewer tot die vorming van diensbare leiers, blyk duidelik uit die voorgaande bespreking. Indien die universiteit sy taak wil bly vervul, moet 'n wisselwerking met die omgewing behou word. Die materiaal van die universiteit is lewende mense wat die ,gees van die tyd" in die universiteit sal indra, en die tydgees het groot waardering vir die liggaamlike opvoeding. „Het is niet waar," skryf Buytendijk (26) „dat opvoeding van houding en beweging, ontwikkeling van kracht en lenigheid, snelheid en uithoudingsvermogen, bchendigheid en beslistheid, van clubgeest en samenspel een teeken is van inzinkende kultuur van den geest, van gemis aan levensernst, van arbeidsonlust, sensaticjacht, eerzucht en wat er zoo meer aan kwaad in den ,geest van den tijd' schuilt." Egte wetenskaplike vorming moet tog ook persoonlikheidsvorming beteken, wat die ontwikkeling van liggaamlike eienskappe insluit.

Die plek wat liggaamlike opvoeding op die universiteite van ander lande inneem, blyk uit die volgende gegewens: In Kanada word 3 uur per week verpligtend vir studente in die eerste jaar toegeken; in Sjina is 3 uur verpligtend vir alle studente op alle universiteite; in Duitsland het elke universiteit sy "Institut fur Leibesübungen"; in Griekenland word 2 tot 3 uur, in Iran 3 uur, in Japan 5 uur, en in die V.S.A. 2 uur per week aan liggaamlike opvoeding gewy. (26).

Die meeste universiteite in Suid-Afrika bied reeds deeglike kursusse vir die opleiding van onderwysers, en hulle beskik oor die nodige fasiliteite. Die grootste meerderheid studente geniet egter geen sistematiese liggaamlike opvoeding nie. Indien minstens een kursus in alle fakulteite vereis word, kan die eerste beginsels van die werking van die liggaam 
en sy organe bygebring word, en aktiwiteite beoefen word wat in die beroepslewe die behoud van liggaamlike geskiktheid sal verseker.

Publieke opinie oor die funksie van die skool is baie konserwatief. Hierdie konserwatisme laat hom veral voel wanneer 'n nuwe vak in die leerprogram opgeneem word. So'n nuwe vak het met sterk en subtiele vooroordele te kampe en die pioniers moet dit verwag en kalm maar vasberade neutraliseer. So is in die verlede dikwels verwys na "strong backs, weak minds," en daarmee die liggaamlike en verstandelike opvoeding teenoor mekaar gestel. Dat die twee dele van die opvoeding in mekaar loop, mekaar aanvul en wedersyds ondersteun in die toerusting van die hele mens, is reeds in prinsipe aangedui maar kan ook proefondervindelik gestaaf word.

Ondersoekinge na die verband tussen geestelike (verstandelike) en liggaamlike prestasies is talryk. Mitchell, Washke, (31) Ray (24) en Hackensmith en Miller (10) het in afsonderlike studies oor hierdie onderwerp in hooftrekke dieselfde gevind, naamlik dat studente wat deelneem aan sportkompetisies (dus goeie atlete) hoër gemiddeldes in akademiese werk behaal as nie-atlete. „For several years there has been a close correlation between high athletic efficiency and a high position in the scholastic standings." Die term "close correlation" van Hackensmith en Miller is egter vaag maar Schwegler en Engelhard (15) gee meer definitiewe resultate oor dieselfde probleem. Hulle vind 'n korrelasie van 29 tussen liggaamlike en geestelike bekwaamheid en ag dit beduidend. Heaton en Hollingworth het albei gevind dat kinders met hoë verstandelike bekwaamheid ook fisies die beste presteer en hoewel indiwiduele afwykinge voorgekom het, is ' $n$ positiewe korrelasie oor die algemeen vasgestel.

Dat die geestelike en liggaamlike vermoëns verband hou en in dieselfde rigting beweeg, is dus bewys. Galton het daarom in 'n mate grond om te verklaar dat 'n span van sy geestelikes enige ander elf in kragsprestasie sou oortref. Indien die goeie liggaamlike moontlikhede deur studie, beroep of leefwyse betreklik onaktief gestel en 'n eensydige geestelike ontwikkeling nagestreef word, verander dic verhoudinge en word die verband versteur tot nadeel en remming van albei.

„Mens sana in corpore sano" word egter dikwels geïnterpreteer asof 'n gesonde gees slegs in 'n gesonde liggaam kan inwoon. Die spreuk was oorspronklik: "laat ons bid dat ons 'n gesonde gees in 'n gesonde liggaam mag hê." (8) Dit is dus nie uitgesluit nie, en inderdaad waar, dat liggaamlik swak persone 'n hoë geestelike bekwaamheid kan besit en dat liggaamlike geskiktheid met min geestelike aanleg gepaard kan gaan. Aan die universiteit neem die geestelike vorming trouens ook 'n eerste 
plek in en word liggaamlike opvoeding ingeskakel omdat dit in die reel ook die geestelike lewe bevorder. Die plek wat liggaamlike opvoeding aan ons inrigting inneem getuig van die besef dat die liggaamlike opvoeding 'n waardevolle bydrae tot die opvoeding van die mens kan lewer. Ons wil dan die liggaamlike opvoeding beoefen om in die eerste plek God ook daardeur te verheerlik en daarbenewens by te dra tot die vorming en volkome toerusting van die mens om geskik te wees tot goeie diens en eindelik ook om die wetenskap van liggaamlike opvoeding te bevorder.

Hooggeagte Here Lede van die Raad en Senaat van die P.U.K. vir C.H.O.,

Ek wil graag by hierdie geleentheid aan u my dank betuig vir die vertroue in my gestel deur my benoeming tot professor in Opvoedkunde. Ek het my gesigspunt oor die doel van liggaamlike opvoeding duidelik probeer stel en aangedui wat ek aan die toekomstige P.U. vir C.H.O. sal nastrewe. Ek beskou dit my plig om die liggaamlike opvoeding te beoefen in die Lig van Gods Woord, en hierdie beginsel oor te plant op ons studente wat die Lig in ons volkslewe verder kan indra. Die aanvaarding van hierdie taak is vir my 'n eer en besondere voorreg. Die taak het $u$ vir my moontlik gemaak nie slegs deur die voorsiening van die nodige fasiliteite nie maar ook deur $u$ gewaardeerde hulp, raad en belangstelling tot die uitbouing van die liggaamlike opvoeding. Vergun my om hier uit te sonder die naam van ons ontslape rektor, prof. dr. F. Postma, wie se bydrae nooit vergeet mag word nie.

Ek wil graag 'n besondere woord van dank aan u, hooggeleerde prof. dr. J. C. Coetzee, uitspreek. Die leiding en vorming wat ek van $u$ kon ontvang gedurende baie studiejare, stel ek hoog op prys. Ek het veel van $u$ geleer. My werksaamhede aan ons inrigting het ek onder $u$, as hoof van die departement Liggaamlike Opvoeding, begin en ek wil u dank vir die groot belangstelling en opoffering gedurende daardie tyd en tot vandag toe.

Aan $\mathfrak{u}$, geagte dames en here studente, wil ek graag my hulp en leiding aanbied wat $u$ by u sportaktiwiteite nodig mag hé, en $u$ van my belangstelling verseker.

Dames en Here, ek dank u vir u welwillende gehoor.

\section{BIBLIOGRAFIE.}

(1) Berry, C. S.: A Broader Concept of Physical Education. Journal of Health and Phys. Educ. Vol. III: 7, 1932.

(2) Carlson, H.: Some Significant Aspects of Physical Education. Journal of Health and Phys. Educ. Vol. VII: 3, 1936. 
(3) Christensen, L. E. and Trap, P. M.: Textbook of Gymnastics. Univ. of London Press, London, 1938.

(4) Clevett, M. A.: An Experiment in Physical Education Activities Related to the Teaching of Honesty and Motor Skills. Research Quarterly of the American Phys. Educ. Ass. Vol. III: 3, 1932.

(5) Cotta, C.: Leitfaden für den Unterricht in der Turngeschichte. Voigtländer Leipzig, 1927.

(6) Die Nasionale Adviserende Raad vir Liggaamlike Opvoeding: Leerplan vir Liggaamlike Opvoeding. Sen. Boek I. Staatsdrukker, Pretoria, 1943.

(7) Duentzer, E. and Hellendall, M.: The Influence of Physical Education Activities upon Constitution, Child-Bearing and Menstruation of Women. Journal of Health and Phys. Educ. Vol. I: 9, 1930.

(8) Euler, C.: Encyklopädisches Handbuch des Gesamten Turnwesens Pichlers, Wien, 1896.

(9) Gaulhofer, K. L.: School en Lichamelijke Opvoeding. Verslag van het Eerste Ned. Congres voor L.O. N.V. Boekhandel, Amsterdam, 1939.

(10) Hackensmith, C. W. and Miller, L.: A Comparison of the Academic Grades and Intelligence Scores of Participants and Nonparticipants in Intramural Athletics at the University of Kentucky. Research Quarterly of the Am. Phys. Educ. Ass. Vol. IX: 1, 1938.

(11) Hawkins, C. C.: Effect of Training in Swimming upon the Morphological Composition of the Blood. Research Quarterly of the Am. Phys. Ed. Ass. (Suppl.) Vol. VI: 2, 1935.

(12) Hecker, W. A. A. en Heyn, A. C.: Geschiedenis der Lichaamsoefeningen van de Oudheid tot Heden. Sijthoff's, Leiden, 1924

(13) Jackson, C. O.: An Experimental Study of the Effect of Fear on Muscle Coordination. Research Quarterly of the Am. Phys. Educ. Ass. Vol. IV: 4, 1933.

(14) Karpovich, P. V.: The Effect of Basketball, Wrestling and Swimming upon the White Blood Corpuscles. Research Quarterly of the Am. Phys. Ed. Ass. (Suppl.) Vol. VI: 2, $19 b 5$.

(15) Korpershoek, J. M. J.: Doel en Plaats der Lichamelijke Opvoeding. Nijgh en van Ditmar's, Rotterdam. 1926.

(16) La Porte, W. R.: Physical Education Contributes to the Seven Cardinal Principles, Journal of Health and Phys. Educ. IV: 3, 1933.

(17) La Porte, W. R.: The Changing Conception of College Physical Education. Research Quarterly of the Am. Phys. Ed. Ass. Vol. II: 1, 1931.

(18): Lee, M.: The Conduct of Physical Education. Barnes and Co., New York, 1937.

(19) McCall, M.: Physical Education a Determining Factor in the Control of the Weight of the College Girl. Research Quarterly of the Am. Phys. Educ. Ass. Vol. IV.: 4, 1933.

(20) McCloy, C. H.: Philosophical Bases for Physical Education. Crofts and Co., New York, 1940.

(21) Mensendieck, B. M.: The Mensendieck System of Functional Exercises. Vol. I. Southworth-Anthoensen Press, Portland, Maine, 1937.

(22) Neumeyer, W. H. and Neumeyer, E. S.: Leisure and Recreation. Barnes and Co., New York, 1949.

(23) Oktavec, F. L.: Physical Education as a Character Builder. Journal of Health and Phys. Educ. Vol. V: 6, 1934. 
(24) Ray, H. C.: Interrelationships of Physical and Mental Abilities and Achievements of High School Boys. Research Quarterly of the Am. Phys. Ed. Ass. Vol. XI: 1, 1940.

(25) Reichs- und Preuszischen Ministerium fur Wissenschaft, Erziehung und Volksbildung: Richtlinien für die Leibeserziehung. Weidmann, Berlín, 1937.

(26) Pijkscollege voor de Lichamelijke Opvoeding: De School en de Lichamelijke Opvoeding. Algemeene Landsdrukkerij, 'S-Gravenhage, 1938.

(27) Rowe, F. A.: Growth Comparison of Athletes and Non-Athletes. Research Quarterly of the Am. Phys. Educ. Ass. Vol. IV: 3, 1933.

(28) Taylor, H. T.: The Implications of Sickness Records of Public School Pupils. Research Quarterly of the Am. Phys. Ed. Ass. Vol. XIII: I, 1942.

(29) Thisted, M. M.: A Study of the Relationship Between Participation in College Athletics and Vocational Success. Research Quarterly of the Am. Phys. Ed. Ass. Vol. IV: 3, 1933.

(30) Turner, C. E. e.a.: Rate of Growth as a Health Index. Research Quarterly of the Am. Phys. Educ. Ass. Vol. VI; 3, 1935.

(31) Washke, P. R.: A Study of Intramural Sports Participation and Scholastic Attainment. Research Quarterly of the Am. Phys. Ed. Ass. Vol. XI: 2, 1940.

(32) Williams, J. F.: A. Fundamental Point of View in Physical Education. Journal of Health and Phys. Educ. Vol. I: I, 1930.

(33) _- Cultural Aspects of Physical Education. Journal of Health and Phys. Educ. Vol. III: 9, 1932.

(34) Yost, F. H.: The Place of Varsity Athletics in a Program of Athletics for All. Journal of Health and Phys. Educ. Vol. II: 6, 1931. 